\title{
Conceptual Teaching Based on Scientific Storyline Method and Conceptual Change Texts: Latitude-Parallel Concepts
}

\author{
Abdulkadir Uzunöz ${ }^{1}$ \\ ${ }^{1}$ Nevşehir Hacı Bektaş Veli University, Faculty of Education, Social Studies, Nevşehir/Turkey \\ Correspondence: Abdulkadir Uzunöz, Nevşehir Hacı Bektaş Veli University, Faculty of Education, Social Studies, \\ Nevşehir/Turkey
}

Received: October 27, 2017

Accepted: November 12, 2017

Online Published: January 29, 2018

doi:10.5430/ijhe.v7n1p32

URL: https://doi.org/10.5430/ijhe.v7n1p32

\begin{abstract}
The purpose of this study is to identify the conceptual mistakes frequently encountered in teaching geography such as latitude-parallel concepts, and to prepare conceptual change text based on the Scientific Storyline Method, in order to resolve the identified misconceptions. In this study, the special case method, which is one of the qualitative research methods, is used and it was conducted with a holistic one-state pattern. As a result of the two-stage diagnostic test applied to fifty (50) ninth-grade students attending a high school in Nevşehir, some preliminary information about the misconceptions about the latitude-parallel concepts have been determined. Students were asked questions about latitude-parallel concepts. The responses obtained from the questions were evaluated with four criteria; understanding, limited understanding, not understanding and misunderstanding. In the study, introductory scientific storyline, which is one of the scientific storyline techniques, has been included in the logical stage of conceptual change text. The concepts are hidden in the narrative, and aimed at the students' analysis and exploration. In the study, it was determined that the students had confused the concepts of latitude-parallel and described them as circular shapes. Conceptual change text has been prepared for eliminating these misconceptions in students.
\end{abstract}

Keywords: Scientific Storyline, Introductory Science Story, Concept Teaching, Misconceptions, Conceptual Change Text, Latitude-Parallel

\section{Introduction}

Learning is the process of evaluating new knowledge in the light of previous ones, and making a subjective judgment. The previous knowledge includes the standards, and criteria on our mind. New knowledge includes the measurements we obtain through our sense organs. Measurements' reaching to a conclusion subsequent to the comparison with the standards in our memory can be qualified as learning. In other words, learning appears when the learners establish an accurate relationship or pattern between the concepts they have just learned and the ones they have had previously (Ausubel, 1963). For that reason, it is remarkable for learners to learn the concepts accurately and in accordance with the scientific truth. The learning of the concepts contrary to the scientific truth causes misconception (Uzunöz, 2013).

The answers of behavioral learning models until 1970s related to how learning appears and the answers of cognitive and constructivist learning models subsequent to this period until now have directed educational systems. The constructivist learning suggests that the learner is active during the learning processes, pre-knowledge of learners is remarkable, because learners have pre-knowledge before the learning activity, and learners build new learning upon the previous knowledge (Piaget, 1976; Huitt and Hummel, 2003).

In constructivist learning theory, conceptual change approach has been used although there have been voiced criticisms on its not regarding the cognitive process of the learner for removing the concept teaching and misconception (Lee and Anderson, 1993). This approach was developed by the science educationalists and philosophers in Cornell University (Posner, Strike, Hewson and Gertzog, 1982). Conceptual change approach is based upon Piaget's balance-imbalance-rebalance principle (Posner, Strike, Hewson and Gertzog, 1982). This principle of Piaget was formulated in two important stages called as assimilation and accommodation from previous knowledge towards new knowledge by Glasersfeld (1995) and Morrison (1998) (Figure 1). In assimilation stage, the learners build new concept to be learned upon old concepts they have, and do not distinguish these two concepts. The 
learners construct the knowledge through generalization. In accommodation stage, the learners construct the concept to be learned through distinguishing from the previous concepts they have.

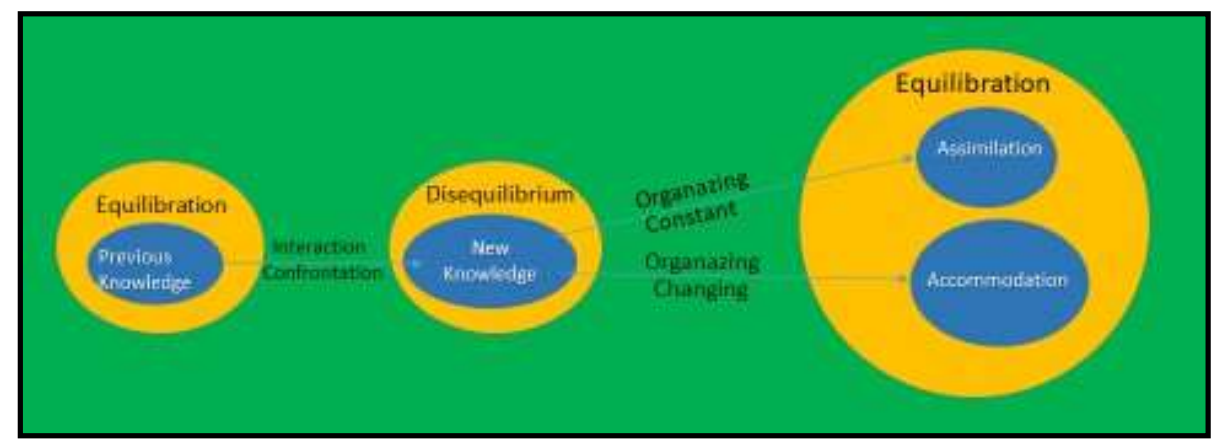

Figure 1. Mental Processes According to Piaget

Reference: Lecture Notes for Geography Teachers and Teacher Candidates "Modular Education Sciences (Uzunöz, 2013).

In conceptual change approach, different techniques are used for overcoming misconception and concept teaching. These are mind map, conceptual network, concept map, knowledge mapping, synectics, prediction-observation-explanation, V/I diagram, concept cartoons, two-tier diagnostic test, conceptual change text, and scientific storyline techniques (Uzunöz, 2013). Furthermore, the technique that is frequently and efficiently used in conceptual change approach is conceptual change text. Conceptual change texts are the documents providing the transformation of students' knowledge on a concept without scientific accuracy into scientific accuracy (Ünal 2007; Uzunöz, 2013). Conceptual change texts include four steps.

1. Dissatisfaction: Students' being aware of their insufficiency on their knowledge for questioning the new knowledge and being dissatisfied from the existing concept.

2. Intelligibility: Students' understanding the new knowledge easily.

3. Plausibility: Learners' finding the new knowledge reasonable; and new knowledge should be consistent with the concept on mind.

4. Fruitfulness: Learners' using the new knowledge for the solution of new possible problems, and transferring this knowledge into another event or daily life. The step of fruitfulness can be associated with the analysis step as cognitive domain steps of Bloom, and creative thinking skill as one of the thinking skills.

Another technique possible to be used for concept teaching in conceptual change approach is scientific storyline. Tepetaş and Haktanır (2013) determined that educational activities depending upon scientific storyline technique were efficient upon increasing the conceptual knowledge of six-year old children. Dinçel (2005) concluded that scientific storyline technique was more efficient for the conceptual development in seventh grade students rather than the traditional method.

Scientific storyline technique creates learning areas in which students compare the previous and new knowledge, and acquire new knowledge by this way, and transfer this new knowledge into new situations. In scientific storyline technique, learning process is organized and planned, and characters are included into the process. In scientific storyline technique, there are events that are worthy of analyzing, and the events include real situations and problems (Bell, 1990). Scientific storyline technique includes the elements of event, action and time. The teacher who uses the technique of scientific storyline prepares texts including a scene, characters and events (Tepetaş and Haktanır, 2013; Yaman and Köstekçi, 1998). With these texts, teachers transfer their thought to students with the events in the story. The action in the story provides students to pass from one event to another, and interaction. Finally, this transition and interaction is noticed to be in a specific time section (Karadağ, 2003). In conclusion, scientific storyline provides stages, order and plan to the teachers for the facts and concepts to be taught from daily life. Scientific storyline is discussed in four different categories (Milne, 1998).

1. Scientific heroic stories: These are about the lives of scientists and persons who contribute upon science.

2. Scientific discovery stories: These are about the scientific discoveries found incidentally.

3. Politically confirmative scientific stories: These are about the mutual interaction of existed or existing different species in world history. 
4. Introductory scientific stories: These are about the scientific concepts.

Geography is an interdisciplinary science between sciences and social sciences (Doğanay, 1999; Özgen, 2010). Interdisciplinary structure of geography science necessitates benefiting from various facts, events and concepts for teaching the geographical subjects (Turan, 2002). On the other hand, geography curriculum also predicts learners' being the active producer of outer world instead of being a passive receiver, structuring the knowledge they observe on their own, and evaluating subjectively (Uzunöz, 2008). For that reason, for an efficient geography teaching, it is necessary to construct information for understanding facts and events better, and to determine misconceptions of students (Cin, 1999). Because learned concept will be the step of the concept to be learned (Akbulut, 2004).

When national and international literature on geographical concepts was revised, the researches on level of understanding the geographical concepts, learning geographical concepts, the geographical concepts that were learned easily and hard, geographical misconceptions and overcoming the misconceptions were remarkable (Milburn, 1972; Harwood and Jackson, 1993; Platten, 1995; Karabağ, 1998; Cin, 1999; Dove, 1999; Taşl1, 2000; Şahin, 2001; Akbaş, 2002; Cin and Yazıcı, 2002; Cin and Özçelik, 2002; Turan, 2002; Coşkun, 2003; Yazıcı and Samanc1, 2003; Başıüyük, Doğar, Gürses and Yazıc1, 2004; Cin, 2004; Demirkaya, Çetin and Tokçan, 2004; Ekiz and Akbaş, 2005; Alkış, 2007; Alim, 2008). It was revealed on teaching geographical concepts and overcoming the mistakes related to geographical concepts that traditional teaching methods were not efficient; however, conceptual change text based on conceptual change approach as one of the active learning methods were efficient (Smith, Blakeslee, \& Anderson, 1993; Hewson, Beeth, \& Thorley, 1998; Dagher, 1994; Mikkila, 2001; Üce and Sarıçayır, 2002; Koray Cansürgü and Bal, 2002; Çepni, Bayri and Özsevgeç, 2007; Ünal, 2007; Akbaş, 2008; Akgün and Aydın, 2009; Akbaş, 2010; Köse, 2011; Akbaş and Uzunöz, 2011; Akbaş and Gençtürk, 2011; Akbaş, Koca and Cin, 2012; Akbaş and Uzunöz, 2013). Moreover, it was also determined that ceonceptual change texts and conceptual cartoons were suggested on teaching the geographical concepts and overcoming the geographical misconceptions, and use of these were common (Akbaş, 2002; Turan, 2006; Alkış, 2007; Akbaş, 2008; Akbaş and Gençtürk, 2011; Uzunöz and Akbaş, 2011; Akbaş, Koca and Cin, 2012; Akbaş and Uzunöz, 2013). However, the activities in which Scientific Storyline technique in conceptual change text was used for overcoming the misconceptions and concept teaching could not be determined.

The students prefer memorizing for learning the geographical concepts especially at the ninth grade (Turan, 2002). Students' not being active in learning the concepts and preferring to memorize causes misconceptions. In this sense, it was considered that carrying out a research on determining the misconceptions for high school ninth grade geography lesson and overcoming these misconceptions would be beneficial upon preventing rote learning. For that reason, it was aimed in this research to prepare conceptual change texts based upon Scientific Storyline method for determining the misconceptions related to the concepts in "Natural Systems Learning Domain/Language of Places: Maps Theme" as the ninth grade geography lesson and overcoming these determined misconceptions.

\section{Method}

In this study, special case method as one of the qualitative research techniques was used. The study was carried out with holistic single-case design. The case researched in this research with qualitative research approach had no concern for generalization because environment, time and persons were specific (Bogdan and Biklen, 1992; Bryman, 1988; Patton, 2002; Silverman, 2000; Stake, 1995). Moreover, because the case to be researched was defined as it was, it did not cause the researcher to make efforts on intervening to any stages of the study, and the students who participated into the study were asked to express their own views, considering their experiences and expectations (Hammersley, 1992; Merriam, 1988; Miles and Huberman, 1994; Patton, 2002; Strauss and Corbin, 1998). The study was carried out following the processes mentioned below.

1. During the interviews with geography teachers carrying on their duties in Nevșehir province on misconceptions, frequently encountered misconceptions of the students were asked. The teacher replied this question as students' having misconceptions on geographical concepts such as latitude-parallel. The teachers suggested that some printed geography books and web-pages relevant or irrelevant to geography used latitude-parallel concepts instead of each other, this caused misconception. This view of teachers was confirmed through the investigations on websites different from each other including geographical subjects and analyzing geography course books printed in different publishing houses for educational grades. Moreover, misconceptions related to these concepts were also noticed in postgraduate and doctoral thesis carried out on misconceptions in our country.

2. It was revealed that the concepts of latitude and parallel had relation with the fifth outcome - Can make inferences about characteristics of age and spatial based on elements of coordinate system and map - of natural systems learning area at ninth grade geography curriculum (Ministry of National Education, MNE, 2011). It was also 
found a relationship between these concepts and the first outcome -can inquiry about mathematical position of Turkey by moving from different location attributes- of "The language of Spatial: Map" theme at geographic location unit in 2017 draft geography curriculum (MNE, 2017).

3. In order to determine the misconception related to the concepts of latitude-parallel, two-tier diagnostic test was performed to fifty (50) ninth grade students studying at a high school in Nevşehir province.

4. Two-tier diagnostic test; in the first tier, a question related to the concept is asked to the student. In the second tier, the reason for the answer of the student is asked, and the student justifies the answer. In conclusion, misconception appears as the student answers wrong and explains the justification (Uzunöz, 2013). The students were firstly asked to define the concepts of latitude and parallel. Secondly, questions such as "Why do you think so?" were asked for the answers they gave for the concepts. For the answers obtained from the test, Plattern's (1995) classification technique for level of understanding the geographical concepts was regarded. The technique included the criteria of understanding, limited understanding, not understanding and misunderstanding. The answers possible to be examples for the criteria were presented to the reader as they were.

1. Understanding: This includes the scientific answer of the question.

2. Limited Understanding: This includes one or more sides of the scientific answer related to the question.

3. Misunderstanding: This includes the answers contrary to the scientific answers.

4. Not understanding: The answers related to the question are not clear and straight. The answers can be as the repetition of the question.

5. For the results of evaluation, reviewing of other researchers on the same discipline was asked. Revisions were provided in accordance with the views. Fit percentage of agreed answers to all answers was calculated to be $\mathrm{P}=.95$. Fit percentage was calculated using the formula of $\mathrm{P}=[(\mathrm{Na}) /(\mathrm{Na}+\mathrm{Nd})]$ x 100 (Miles and Huberman, 1994). "P" indicated the fit/agreement percentage, "Na" indicated the fit rate/agreement, and " $\mathrm{Nd}$ " indicated Disagreement rate/disagreement. So that reliability of the research was aimed to be provided. In order to increase internal reliability and validity of the research findings, views of students were presented with direct quotations.

6. In order to overcome misconceptions determined as result of the two-tier diagnostic test, conceptual change text was prepared with introductory Scientific Storyline technique. The conceptual change text was prepared according to the steps of dissatisfaction, intelligibility, plausibility, and fruitfulness determined by Posner, Strike, Hewson and Gertzog (1982).

7. Scientific Storyline technique was used in plausibility step of conceptual change text prepared for overcoming the misconceptions. Scientific Storyline technique used in the research means introductory scientific storytelling processing the scientific concepts (Milne, 1998). The story was prepared according to the steps developed by Labov (1982). The concepts were hidden in the story, and the students were aimed to determine, solve and discover the concepts. This was the superior aspect of introductory scientific storyline from other techniques. Prepared story included introduction, body, node, solution and conclusion sections.

8. The story was finalized under the revision of three Turkish department lecturers.

9. Prepared conceptual change text was analyzed with a geography lecturer carrying on duty in a faculty of education at a state university, and a lecturer carrying on duty in geography department of faculty of arts and science. Furthermore, two geography teachers and two Turkish teachers carrying on their duties at schools affiliated to Ministry of National Education also revised the prepared texts.

10. Before finalizing the conceptual change text developed for overcoming the misconceptions, pilot implementation was performed with a volunteer student group including 5 students studying at the ninth grade of an Anatolian high school. At the end of pilot implementation and expert views, conceptual text change was finalized, and became ready for the implementation.

\section{Findings}

In this section, two-tier diagnostic test result performed for determining the misconceptions of students related to the concepts of "latitude and parallel," and in-class implementation examples of conceptual change text prepared for these concepts were included.

\section{Thoughts of Students on the Concepts of Parallel-Latitude}

The students defined latitude and parallel interchangeably. Furthermore, they told that latitude and parallel were circular lines. According to some students, latitude and parallel were the same. According to some other students, 
latitude and longitude were the same. Whereas one student thought that parallel and latitude were the shape of the world, one student explained that latitude and parallel helped people to express geography. Students based their thoughts on books, internet resources, maps, lessons, school and what they read.*

\section{Question 1: What do you think about parallel and latitude?}

Student 11: "Parallels are totally 180 imaginary lines including 90 on the north and 90 on the south drawn with 1 degree interval as parallel to each other on the World."(Understanding)

Student 47: "The circular lines we considered to be existing with 1 degree intervals including 90 on the north and 90 on the south on the World are called latitude or parallel." (Limited understanding)

Student 25: "Latitude and parallel are the imaginary lines assumed to pass through the World with equal intervals horizontally. The biggest latitude is Equator."(Limited understanding)

Student 21: "These are the lines passing through the world horizontally." (Limited understanding)

Student 4: "Parallel or latitude extends from one end to another on a horizontal plane." (Misunderstanding)

Student 7: "Length of the parallels decreases from Equator to both Poles." (Misunderstanding)

Student 5: "Parallel and latitude are the shapes used for calculating time." (Misunderstanding)

Student 50: "Latitude and parallels help people to introduce geography as more easily and understandably." (Not understanding)

Student 8: "Parallel and latitude are the shape of the world." (Not understanding)

Question 2: Why do you think so?

Student 11: "I learned so; it is mentioned like this in books and on the internet."

Student 47: "Because latitude and parallel are the same. Because the world is spherical. The lines are also spherical because they are around the World and cover the entire World."

Student 25: "I learned so at school, this information was also present in supplementary books I read and on the internet."

Student 21: "They pass through latitudinally when we look at maps and globe."

Student 4: "I saw on a map."

Student 7: "These were taught in Geography lesson."

Student 5: "We did it in the lesson; we calculated the time difference between Nevşehir and Ankara."

Student 50: "What I read and what they taught me made me think so."

Student 8: "I learned from the internet."

\section{In-Class Implementation of Conceptual Change Text}

The conceptual change text was handed out to the students by the teacher. The students were asked to think and discuss the questions on the first section of the conceptual change text. The teacher asked the questions to the student 10 minutes later. The answers of the students were projected to the board. So that, the students were provided to understand their incompetence. This stage was the dissatisfaction stage. Misconceptions in the conceptual change text were read by the teacher. Subsequently, thoughts of students about the misconceptions read by the teacher were asked. In this stage, views of students related to the concept were listened. However, no feedback was given to the students by the teacher on accuracy or incorrectness of their answers. This stage was intelligibility stage. Then, the students were asked to read introductory scientific story including clue scientific truths. The students were let 10 minutes to read the story. This was the plausibility stage. Finally, the students were asked to answer the assessment questions according to the reading text. This was the fruitfulness stage. The students were let 10 minutes for this activity.

\section{Latitude and Parallel Conceptual Change Text}

Study sheets including the conceptual change text related to latitude and parallel concepts were prepared considering the conceptual change approach of Posner, Strike, Hewson and Gertzog (1982). The study sheets included four (4) activities related to formal section, implementation process and dissatisfaction, intelligibility, plausibility, and fruitfulness. 


\section{Conclusion}

By means of this study, the misconceptions related to the concepts of latitude and parallel in the fifth acquisition included in geography curriculum natural systems learning domain or second acquisition of 2017 draft geography curriculum of "Language of Place: Maps Theme" were determined. The students were determined to use the concepts of parallel and latitude interchangeably. Furthermore, the students were also noticed to have inaccurate knowledge on the concepts of circle and sphere. It was determined that because the students accepted the concepts of circle and sphere as the same, and used them interchangeably, they used the expression of latitude-parallel sphere instead of parallel-latitude circle. The reasons for these misconceptions noticed in the students could be listed as inaccurate learning in mathematic lessons, and their accepting the information in course books, webpages and mass media as correct. Namely, students could be mentioned as including the knowledge they encountered in daily life into the classroom environment.

On the other hand, conceptual change texts were noticed to be frequently used for determining and overcoming the science and geography, even little, misconceptions. In the researches, it was determined that conceptual cartoons were included in plausibility stage of the conceptual change texts. The conceptual change text used in this research included the introductory scientific stories developed first by the researcher. This aspect of the research was considered to provide technical contribution upon the studies limited on teaching of geographical concepts in our country.

\section{Recommendations}

1. The concepts in acquisitions of the geography curriculum, and misconceptions noticed in these concepts should be determined and overcome.

2. Conceptual change texts were considered to be beneficial for teaching geographical concepts when implemented with the storyline technique.

3. Mind maps, conceptual network, concept maps, knowledge mapping, synectics, semantic analysis tables, prediction-observation-explanation, V/I diagram, concept cartoons, two-tier diagnostic test, conceptual change text, and scientific storyline techniques can be used besides the conceptual change texts. Furthermore, different studies can be carried out for determining the efficiency of these techniques.

4. The curriculums updated in 2015 led to activity-based teaching services. Activity-based learning can be considered to get students and teachers adopt conceptual change texts, and provide them to use these texts efficiently.

5. Course books, students' study books, and teachers' guide books should be prepared considering the misconceptions of students.

6. Teachers should develop and use activities based upon different methods and techniques for overcoming the misconceptions of students. To achieve this, in-service trainings should be organized for teachers (Uzunöz, 2004).

7. Web pages should not mostly be indicated as the reference, and students should be warned on these.

8. For course book, social media, web page and informative communication technology based misconceptions, media literacy seminars should be organized for teachers and students.

\section{References}

Akbaş ve Gençtürk (2011). The Effect of Conceptual Change Approach to Eliminate 9th Grade High School Students' Misconceptions about Air Pressure.Educational Sciences: Theory and Practice, 11(4).

Akbaş, Y. (2002). İlköğretim 6. Sınıf Öğrencilerinin Coğrafi Kavramları Anlama Düzeyleri ve Kavram Yanılgıları. (Yayınlanmamış Yüksek Lisans Tezi), Karadeniz Teknik Üniversitesi Sosyal Bilimler Enstitüsü, Trabzon.

Akbaş, Y. (2008). Ortaöğretim 9. sınıf öğrencilerinin iklim konusundaki kavram yanılgılarının giderilmesinde kavramsal değişim yaklaşımının etkisi. Unpublished Master Thesis] Atatürk Üniversitesi, Sosyal Bilimler Enstitüsü, Erzurum.

Akbaş, Y. (2010). The Effect of a Conceptual Change Approach on Eliminating Students' Misconceptions about Air Pressure. İstanbul, Turkey, 8, 261.

Akbaş, Y. ve Uzunöz, A. (2013). Ortaöğretim dokuzuncu sınıf öğrencilerinin nem kavramıyla ilgili yanılgılarını gidermede kavramsal değişim yaklaşımının etkililiği. Kastamonu Eğitim Dergisi,21/2.

Akbaş, Y., Koca, H., \& Cin, M. (2012). Ortaöğretim 9. Sınıf Öğrencilerinin Nem Kavramıyla İlgili Yanılgılarını Gidermede Kavramsal Değişim Yaklaşımının Etkinliği. Doğu Coğrafya Dergisi. 
Akbulut, G. (2004). Coğrafya Öğretimi ve Yaratıcı Düşünce. Cumhuriyet Üniversitesi Sosyal Bilimler Dergisi Cilt: 28(2).

Akgün, A., \& Aydın, M. (2009). Erime ve çözünme konusundaki kavram yanılgılarının ve bilgi eksikliklerinin giderilmesinde yapılandırmacı öğrenme yaklaşımına dayalı grup çalışmalarının kullanılması. Elektronik Sosyal Bilimler Dergisi, 8(27).

Alim, M. (2008). Öğrencilerin Lise Coğrafya Öğretim Programında Yer Alan Yer Yuvarlağı ve Harita Bilgisi Ünitelerindeki Bazı Kavramları Anlama Düzeyleri ve Kavram Yanılgıları, Milli Eğitim Dergisi, 177/1, 166-177.

Alkış, (2007).İlköğretim Beşinci Sınıf Öğrencilerinin Nem Kavramını Algılamaları Üzerine Bir Araştırma, Illkögretim Online, 6(3).

Ausubel, D. "Educational psychology: A cognitive view", New York: Holt, Rinehart, and Winston, 1963

Başıüyük, Doğar, Gürses ve Yazıcı (2004). Öğrenim Öğrencilerinin Hava ve İklim Olaylarını Anlama Seviyeleri ve Kavram Yanılgıları, Milli Eğitim Dergisi, Sayı:162 (Bahar), Ankara.

Bell, S. (1990). Steve Bell's Secret Notebook to Create Learning. European Association for Educational Design.

Bogdan, R. C., and Biklen, S. K. (1992). Qualitative Research for education: An Introduction to Theory and Methods, London: Allyn \& Bacon.

Bryman, A. (1988). Quantity and quality in social research. London \& New York: Routledge. https://doi.org/10.4324/9780203410028

Canpolat, N., (2002). Kimyasal Denge ile İlgili Kavramların Anlaşılmasında Kavramsal Değişim Yaklaşımının Etkinliğinin İncelenmesi, Atatürk Üniversitesi Fen Bilimleri Enstitüsü, Yayınlanmamış Doktora Tezi, Erzurum.

Cin, M. (1999). The influence of direct experience of the physical environment on concept learning in physical geography. Unpublished EdD Thesis, University of Durham.

Cin, M. (2004). İlkokul 1. Sınıf Öğrencilerinin Deniz Kavramını Algılamaları Üzerine Bir Araştırma, Kuram ve Uygulamada Eğitim Bilimleri, Educational Sciences: Theory \& Practice, Volume 4, Issue 1 (May), Ankara.

Cin, M., \& Özçelik, İ. (2002). A review of the literature on concept learning in physical geography. Boğaziçi University Journal of Education, 19(1), 61-76.

Cin, M., \& Yazic1, H. (2002). The influence of direct experience on children's ideas about the formation of the natural scenery. International Research in Geographical and Environmental Education,11(1). https://doi.org/10.1080/10382040208667459

Coçkun, M. (2003). Cografya ögretiminde nem konusundaki kavram yanliçliklan ve giderilmesine yönelik öneriler. Gazi Egitim Fakültesi Dergisi, 23(3), 147-158.

Coştu, B. (2006). Kavramsal Değiş̧imin Gerçekleşme Düzeylerinin Belirlenmesi: Buharlaşma, Yoğunlaşma ve Kaynama. Doktora Tezi, KT Ü. Fen Bilimleri Enstitüsü, Trabzon.

Çepni, S., Taş, E., \& Köse, S. (2006). The effects of computer-assisted material on students' cognitive levels, misconceptions and attitudes towards science. Computers \& Education, 46(2). https://doi.org/10.1016/j.compedu.2004.07.008

Dagher, Z. R. (1994). Does the use of analogies contribute to conceptual change? Science education, 78(6). https://doi.org/10.1002/sce.3730780605

Demirkaya, H., ÇETiN, T., \& Tokcan, H. (2004). İlköğretim Birinci Kademe Öğrencilerine Yön Kavramı Öğretiminde Kullanılabilecek Metotlar. Gazi Üniversitesi Gazi Eğitim Fakültesi Dergisi, 24(3).

Dincel, M. (2005). Öyküleme ve deney tekniğinin fen bilgisi dersinde öğrencilerin kavramsal anlama ve başarılarına etkisi. Yayınlanmamış Yüksek Lisans Tezi. Marmara Üniversitesi, Eğitim Bilimleri Enstitüsü, İstanbul.

Disessa, A. A. (2002). Why "conceptual ecology" is a good idea. In Reconsidering conceptual change: Issues in theory and practice (pp. 28-60). Springer Netherlands. https://doi.org/10.1007/0-306-47637-1_2

Doğanay, H. (1999). Coğrafya'ya Giriş. Konya: Çizgi Kitapevi.

Dove, J. (1999) Immaculate Misconceptions (this series). Sheffield: Geographical Association.

Ekiz, D. ve Akbaş, Y. (2005). İlköğretim 6. Sınıf Öğrencilerinin Astronomi ile İlgili Kavramları anlama Düzeyi ve Kavram Yanılgıları, Milli Eğitim Dergisi, Sayı: 165. 
Glasersfeld, E. V. (1995). A constructivist approach to teaching. Constructivism in education, 3-15.

Hammersley, M. (1992).What's wrong with ethnography?. London: Routledge.

Harwood, D. \& Jackson, P. (1993). "Why did they build this hill so steep?” Problems of assessing primary children's understanding of physical landscape features in the contexs of the UK national curriculum. Geographic and Environmental Education, 2 (2), 6.

Hewson, M. G., \& Hewson, P. W. (1983). Effect of instruction using students' prior knowledge and conceptual change strategies on science learning. Journal of Research in Science Teaching, 20(8), 731-743. https://doi.org/10.1002/tea.3660200804

Hewson, P. W., Beeth, M. E., \& Thorley, N. R. (1998). Teaching for conceptual change. International handbook of science education, 2, 199-218. https://doi.org/10.1007/978-94-011-4940-2_13

Huitt, W., \& Hummel, J. (2003). Piaget's theory of cognitive development.Educational psychology interactive, 3(2), $1-5$.

Karabağ, S. (1998). Coğrafya öğretiminde anahtar sorular ve kavramlar. Gazi Eğitim Fakültesi Dergisi, 18(2), 25-41.

Karadağ, Ö. (2003). Türkçe eğitiminde anlatım tarzları. Türklük Bilimi Araştırmaları, 13(13), 79.

Koray, Ö. C., \& Bal, Ş. (2002). Fen öğretiminde kavram yanılgıları ve kavramsal değişim stratejisi. Kastamonu Eğitim Dergisi, 10(1), 83-90.

Köse, S., Ayas, A., \& Taş, E. (2003). Bilgisayar destekli öğretimin kavram yanılgıları üzerine etkisi: Fotosentez. Pamukkale Üniversitesi Ĕgitim Fakültesi Dergisi, 14(2), 106-112.

Köse, S., Kaya, F., Gezer, K., Kara, İ. (2011). Bilgisayar Destekli Kavramsal Değişim Metinleri: Örnek Bir Ders Uygulaması. Pamukkale Üniversitesi Eğitim Fakültesi Dergisi, Say1 29 (Ocak 2011/I), ss. 73-88.

Labov, W. (1982) "Speech actions and reactions in personal narrative", in D. Tannen (ed) Analyzing Discourse: Text and Talk, Washington DC, Georgetown University Press.

Lee, O., \& Anderson, C. W. (1993). Task engagement and conceptual change in middle school science classrooms. American Educational Research Journal,30(3), 585-610. https://doi.org/10.3102/00028312030003585

MEB. (2011). 2005 Coğrafya Dersi Öğretim Programı (9, 10, 11 ve 12. Sınıflar).Talim Terbiye Kurulu Başkanlığı.

MEB. (2017). 2017 Coğrafya Dersi Çerçeve Öğretim Programı (9, 10, 11 ve 12. Sınıflar).Talim Terbiye Kurulu Başkanlığı.

Merriam, S. B. (1988).Case study reseacrh in education: A qualitative aproach, San Francisco, CA: Jossey-Bass.

Mikkilä-Erdmann, M. (2001). Improving conceptual change concerning photosynthesis through text design. Learning and Instruction, 11(3). https://doi.org/10.1016/S0959-4752(00)00041-4

Milburn, D. (1972). Children's vocabulary. New movements in the study and teaching of geography, 107-120.

Miles, M. B, and Huberman, A. M. (1994).Qualitative data analysis: An expanded sourcebook, (second edition), Newbury Park, CA: Sega.

Milne, C. (1998). Philosophically correct science stories? Examining the implications of heroic science stories for school science. Journal of Research in Science Teaching, 35(2), 175-187. https://doi.org/10.1002/(SICI)1098-2736(199802)35:2<175::AID-TEA7>3.0.CO;2-P

Morrison, G. S. (1998). Jean Piaget: a new way of thinking about thinking. Early Childhood Education Today. Charles R. Merrill Publishing Company.

Ölmez, O., Geban, Ö., \& Ertepınar, H. (2001). Dördüncü sınıf öğrencilerinin dünya ve gökyüzü konularındaki kavramları anlamalarında kavramsal değişim yaklaşımının etkisi. Bilimde Çağdaş, Düşüncede Özgür Yeni Binyılın Başında Türkiye'de Fen Bilimleri Eğitimi Sempozyumu. Maltepe University. September 7-8.

Özgen, N. (2010). Bilim Olarak Coğrafya ve Evrimsel Paradigmaları. Ege Coğrafya Dergisi, 19(2).

Özkan, Ö. (2001). Remediation of Seventh Grade Students' Misconceptions Related to Ecological Concepts Through Conceptual Change Approach. ODTÜ, Basılmamıß̧ Yüksek Lisans Tezi, Ankara.

Özmen, H., Demircioğlu, G., (2003), Asitler ve Bazlar Konusundaki Öğrenci Yanlış Anlamalarının Giderilmesinde Kavram Değişim Metinlerinin Etkisi, Milli Eğitim Dergisi, Sayı:159, s.111-119. 
Özsevgeç, T., Çepni, S., \& Bayri, N. (2007). Kalıcı Kavramsal Değişimde 5E Modelinin Etkililiği. EDU7, 2(4).

Palmer, D. H. (2003). Investigating the relationship between refutational text and conceptual change. Science Education, 87(5), 663-684. https://doi.org/10.1002/sce.1056

Patton, M.Q. (2002). Qualitative research \& evaluation methods. (3 Edition). New Castle, NE: Sage.

Piaget, J. (1976). Piaget's theory. In Piaget and his school (pp. 11-23). Springer Berlin Heidelberg. https://doi.org/10.1007/978-3-642-46323-5_2

Platten, L. (1995). Talking Geography: an Investigation into Young Children's Understanding of Geographical Terms Part-1, International Journal of Early Years Education, Vol:3, N:1.

Posner, G. J., Strike, K. A., Hewson, P. W., \& Gertzog, W. A. (1982). Accommodation of a scientific conception: Toward a theory of conceptual change. Science education, 66(2), 211-227. https://doi.org/10.1002/sce.3730660207

Silverman, D. (2000). Doing qualitative research: A practical handbook, London: Sage, (2000).

Smith, E. L., Blakeslee, T. D., \& Anderson, C. W. (1993). Teaching strategies associated with conceptual change learning in science. Journal of Research in Science Teaching, 30(2), 111-126. https://doi.org/10.1002/tea.3660300202

Stake, R. E. (1995). The art of case study research, London: Sage.

Strauss, A.L. and Corbin, J., (1998). Basics of qualitative research, (second edition), Newbury Park, CA: Sage.

Şahin, F. (2001). Öğretmen adaylarının kavram haritası yapma ve uygulama hakkındaki görüşleri. Pamukkale Üniversitesi Ĕ̈itim Fakültesi Dergisi, 10(10), 12-25.

Taşlı, İ. (2000). Günümüz coğrafya öğretiminde öğrenci aktivitelerinin bilgi üretimine dönüştürülmesinde olgular, kavramlar ve genellemelerin sistematik kullanımının sağlanması. Milli Eğitim Dergisi, 145.

Tepetaş, G. Ş., \& Haktanır, G. (2013). 6 Yaş Çocuklarının Temel Kavram Bilgi Düzeylerini Desteklemeye Yönelik Bilimsel Öyküleştirme Yöntemine Dayalı Bir Eğitim Uygulaması. Eğitim ve Bilim, 38(169).

Turan, İ. (2002). Lise coğrafya derslerinde kavram ve terim öğretimi ile ilgili sorunlar. Gazi Üniversitesi Gazi Eğitim Fakültesi Dergisi, 22(2).

Turan, İ. (2006). Sınıf öğretmenliği programı öğrencilerinin coğrafi kavramları öğrenme düzeyleri ve ezbercilik. Milli Eğitim Dergisi, 170, 274-293.

Uzunöz, A. (2004). Ortaöğretim Coğrafya öğretmenleri ve öğrencilerinin coğrafya öğretiminin genel amaçlarına ulaşma düzeyinin belirlenmesi (Master Thessis, KTÜ, Sosyal Bilimler Enstitüsü).

Uzunöz, A. (2008). Ortä̈ğretim dokuzuncu sınıf coğrafya dersinde çoklu zekâ destekli öğretimin öğrenci başarısı tutumu ve kalıcılığa etkisi (Doctoral dissertation, DEÜ Eğitim Bilimleri Enstitüsü).

Uzunöz, A. (2013). Coğrafya Öğretmenleri ve Öğretmen Adayları için Ders Notları "Modüler Eğitim Bilimleri”. Trabzon: Eser Ofset.

Uzunöz, A., \& Akbaş, Y. (2011). Teach of Geography Based on Conceptual Chance Approach; an Example of Implementation.Education Sciences, 6(2), 1659-1678.

Üce, M., \& Sarıçayır, H. (2002). Üniversite 1. sınıf genel kimya dersinde asit-baz konusunun öğretiminde kavramsal değişim metinleri ve kavram haritalarının kullanılması. MÜ Atatürk Eğitim Fakültesi Eğitim Bilimleri Dergisi, 16, 163-170.

Ünal, S. (2007). Atom ve Molekülleri Bir Arada Tutan Kuvvetler Konularının Öğretiminde Yeni Bir Yaklaşım: BDÖ ve BDM'nin Birlikte Kullanımının Kavramsal Değişime Etkisi, Yayınlanmamış Doktora Tezi, KTÜ, Fen Bilimleri Enstitüsü, Trabzon.

Yaman, E., Köstekçi, M. (1998). Türk Dili ve Kompozisyon. Ankara: Gazi Kitabevi.

Yazıcı H. ve Samancı, O. (2003). İlköğretim Öğrencilerinin Sosyal Bilgiler Ders Konuları İle İlgili Bazı Kavramları Anlama Düzeyleri. Milli Eğitim Dergisi, 158(2003), 2-6. 


\section{Extended Abstract}

Learning is permanent, cognitive, emotional, and kinesthetic changes obtained by appropriate patterns when comparing old concept knowledge with new concept knowledge. Concept teaching is important for a permanent learning. The concepts should be clear, understandable and scientific for students. If students learn concepts in a non-scientific way and misconceptions occur, these errors should be identified and corrected. The purpose of this study is to identify the conceptual mistakes frequently encountered in teaching geography such as Latitude-Parallel, concepts, and to prepare conceptual change texts based on the Scientific Storyline Method, in order to resolve the identified misconceptions. In this study, the special case method which is one of the qualitative research methods is used and it was carried out with a holistic single case design by following the steps below. Negotiations were made about misconceptions, with a group of geography teachers working in Nevşehir. The teachers involved were asked about the misconceptions frequently seen in the students. They have pointed out that misconceptions are often seen in students in geographic concepts such as latitude-parallel. They have argued that in some geography books and on some web pages that are related to geography or not, misuse of latitude and parallel concepts causes misconceptions. These views of teachers are confirmed by examinations of geography textbooks published in different publishing houses for the learning steps and and also by examinations on different web sites where geographical topics are involved as well. It has been found that the concepts of Latitude-Parallel in the current geography curriculum are related to the fifth acquisition (finds out about the properties of time and place, starting from the elements that make up the coordinate system and the map) in the field of natural systems learning in the ninth grade program. And in the 2017 draft geography curriculum, it was found to be associated with the first acquisition (moving from different location features, questions Turkey's mathematical position) of the 'Geography of the Place: Maps Theme: Geographic Location' unit. A two-step diagnostic test was applied to fifty (50) ninth-grade students studying in a high school in Nevşehir to determine the latitude-parallel misconception. In the first step of the Two-Step Diagnostic Test, students are asked questions about the concept. In the second phase; The reason for the answer given by the student is asked and the student shows reasons. As a result, misconceptions arise when the student gives the wrong answer and explains the reason. Students are first asked to define latitude-parallel concepts. In the second step, students were asked about the answers to the concepts, "Why do you think so?" For the responses obtained from the test, the technique of classifying the understanding level of Plattern geographical concepts was taken into consideration. This technique consists of the criteria of understanding, limited understanding, not understanding and misunderstanding. The answers to the relevant criteria were presented to the reader without any change. Other researchers working in the same field were consulted for the evaluation results. Arrangements have been made in line with opinions. Percentage of agreement was calculated as $\mathrm{P}=.95$, as the responses to the consensus were proportional to all answers. Thus, it is aimed to ensure the reliability of the research. In order to increase the internal reliability and validity of the findings of the research, direct citations were made to the opinions of the students. The conceptual change text has been prepared with the Introductory Scientific Storyline Technique to eliminate the misconceptions detected in the two-stage diagnostic test. The conceptual change text was prepared according to the inadequacies, understandability, reasonableness and efficiency stages that Posner, Strike, Hewson and Gertzog identified. Scientific Storyline Technique was used in the logic stage of the conceptual change text prepared to eliminate the misconceptions. The Scientific Storyline technique used in the research is an introductory scientific storytelling in which scientific concepts are processed. The story was prepared according to the steps developed by Labov. The concepts are concealed within the narration and aimed at the students to identify and analyze the concepts. This is the superior aspect of the introductory scientific storyline that separates it from other techniques. The prepared story consists of introduction, development, node, solution and result parts. The story was finalized under the supervision of three lecturers from the Turkish Language Department who are experts in their field. The conceptual change text was prepared by a faculty member working in a geography department of education faculty of a state university and a faculty member working in the science and literature faculty geography department. In addition, two geography teachers who are working in schools affiliated to the Ministry of National Education and two Turkish teachers have also studied the texts prepared. A pilot study was conducted with a volunteer group of 5 students, who are in the ninth grade of an Anatolian high school in Nevssehir, before giving the final shape to the conceptual change text developed to eliminate misconceptions. As a result of pilot study and expert opinion, the conceptual change text has been finalized and is ready for implementation. Conceptual change texts are one of the effective methods used to correct conceptual misconception. Conceptual change texts consist of inadequacy, reasoning, understandability, efficiency. In the study, introductory scientific storyline, which is one of the scientific narrative techniques in the logical stage of conceptual change texts, has been used. The concepts are concealed within the narrators and aimed at the students' analysis and exploration. The stories consist of introduction, development, node, solution and result parts. In the study; it is seen that students have misinformation about the 
concepts of circles and circular regions. It was found that students used the latitude-parallel circular region instead of the latitude-parallel circle, because they regarded the circle and circular region concept as the same and used both as same concepts. Correct acceptance of information learned from math lessons, textbooks, web pages and mass media can be listed as reasons for these misconceptions in students.

Appendix

\begin{tabular}{|c|c|}
\hline Name of the Activity: & "WHAT IS LATITUDE?" \\
\hline Grade/Class: & $9^{\text {th }}$ Grade \\
\hline Learning Domain/Theme & NATURAL SYSTEMS/LANGUAGE OF PLACE: MAPS \\
\hline Acquisition: & $\begin{array}{l}\text { 9.5. Making inference on properties of time and place depending } \\
\text { upon coordinate system and factor creating a map (MNE 2011). } \\
\text { 9.2.1.1. Questioning the mathematical location of Turkey } \\
\text { depending upon different location properties (MNE, 2017) } \\
\text { Skill: Questioning }\end{array}$ \\
\hline Number of Students: & Class Size \\
\hline Time: & 45 Minutes \\
\hline Place of Implementation: & Classroom \\
\hline $\begin{array}{l}\text { Order of the Place for } \\
\text { Implementation: }\end{array}$ & In Groups \\
\hline Material: & Smart Board, Pictures, Map, T-shirts, Story \\
\hline $\begin{array}{l}\text { Relation with Other Lessons /Basic } \\
\text { Skills: }\end{array}$ & $\begin{array}{l}\text { Geometry } \\
\text { 11.4.1. Explain circle, fundamental and supplementary elements } \\
\text { and make practices. } \\
\text { (Basic Skills: Using figures, pictures, tables, etc.) } \\
\text { Visual Arts } \\
\text { 9.7.8. Making circular perspective drawing. } \\
\text { (Basic Skills: Critical Thinking, Creative Thinking, Observation, } \\
\text { and Visual Perception) } \\
\quad \text { Physics } \\
\text { 12.1.1. Explaining regular circular movement and giving } \\
\text { examples from daily life. } \\
\text { 12.1.2. Explaining the concepts of period, frequency, linear } \\
\text { velocity and angular velocity in regular circular movement, and } \\
\text { correlating these with each other. } \\
\text { 12.1.5. Analyzing the movements of objects acting as regular } \\
\text { circular in daily life. } \\
\text { 12.1.7. Defining the problem status from daily life related to } \\
\text { regular circular movement, and making solution-based designs. } \\
\text { (Basic Skills: Determining the Problem, Defining the Cause and } \\
\text { Result Relationships) } \\
\text { Astronomy } \\
\text { 1.5. Establishing relationships between astronomy and other } \\
\text { disciplines. } \\
\text { 2.2. Explaining that time is relative benefiting from the } \\
\text { astronomic observations. } \\
\text { 3.6. Finding a point with geographical coordinates on a model. }\end{array}$ \\
\hline
\end{tabular}




\begin{tabular}{|c|c|}
\hline & $\begin{array}{l}\text { 4.1. Explaining the annual movement of the Sun. } \\
\text { 4.2. Predicting equatorial axial numbers of the Sun for a } \\
\text { determined specific period approximately. } \\
\text { (Basic Skills: Critical Thinking, Creative Thinking, Reasoning, } \\
\text { Correlating, Making Observation) }\end{array}$ \\
\hline Instructional Techniques: & Discussion, Interpretation, Brainstorming, Question \& Answer \\
\hline Regarded Principles: & $\begin{array}{l}\text { 1. Suitability to Students } \\
\text { 2. Vitality } \\
\text { 3. Active Participation } \\
\text { 4. Actuality } \\
\text { 5. From Concrete to Abstract } \\
\text { 6. From Simple to Complicated } \\
\text { 7. From Known to Unknown } \\
\text { 8. From Closer to Distant } \\
\text { 9. Economy }\end{array}$ \\
\hline \multicolumn{2}{|l|}{ Process of Implementation } \\
\hline \multicolumn{2}{|c|}{$\begin{array}{l}\text { 1. "IF LATITUDE INTERVENES INTO CONVERSATION" was handed out to the students in turn. } \\
\text { 2. The students were asked to answer the questions in study sheets by discussing, and write the answers intc } \\
\text { gaps left for each question. The students were let } 10 \text { minutes for answering the questions. }\end{array}$} \\
\hline \multicolumn{2}{|c|}{$\begin{array}{l}\text { 3. The answers of the students to the activity of "THE ROAD FROM LATITUDE TO REWARD" were got } \\
\text { to some students read aloud. The students were asked to answer the questions in the activity of "DON'T TELL } \\
\text { INSUFFICIENT, THESE ANSWERS ARE SUFFICIENT, FRIENDS" according to these answers. The } \\
\text { students were let } 10 \text { minutes for answering the questions. }\end{array}$} \\
\hline \multicolumn{2}{|c|}{$\begin{array}{l}\text { 4. The students were asked to read the "Reading Text" titled as "WHAT ARE PARALLEL AND } \\
\text { LATITUDE, WHAT ARE NOT?" The students were let } 10 \text { minutes for answering the questions. }\end{array}$} \\
\hline \multicolumn{2}{|c|}{$\begin{array}{l}\text { 5. The students were asked to answer the questions in the activity of "LET'S PUT OUR KNOWLEDGE ON } \\
\text { A SCALE," and write the answers into gaps left for each question. The students were let } 10 \text { minutes for } \\
\text { answering the questions. }\end{array}$} \\
\hline \multicolumn{2}{|c|}{$\begin{array}{l}\text { 6. At the end of the time, each student read the answer aloud. Similar answers were grouped, and the students } \\
\text { were asked to make peer assessment. }\end{array}$} \\
\hline \multicolumn{2}{|l|}{ Assessment } \\
\hline \multicolumn{2}{|c|}{$\begin{array}{l}\text { 1. Study sheets including the correct answers were projected on board in slides. } \\
\text { 2. The students who answered the questions correctly took one plus. }\end{array}$} \\
\hline
\end{tabular}

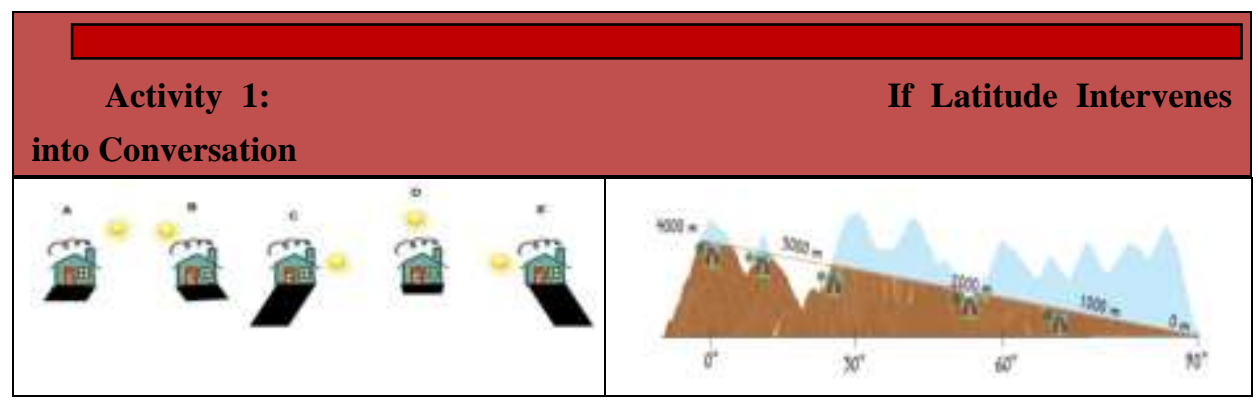

Figure 1. Change of shade length during the day
Figure 2. Sun's angle of incidence and lower limit of permanent snow 


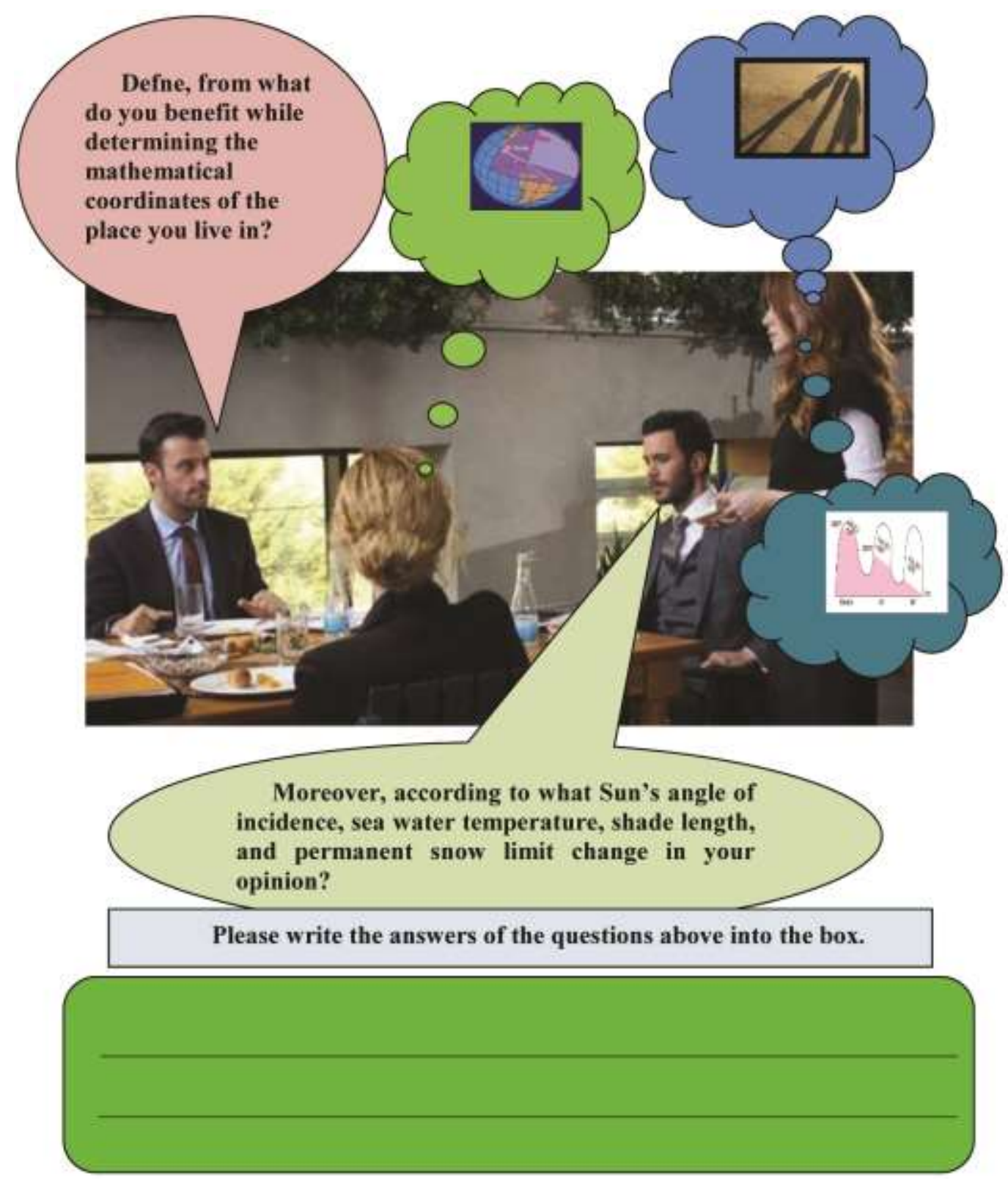



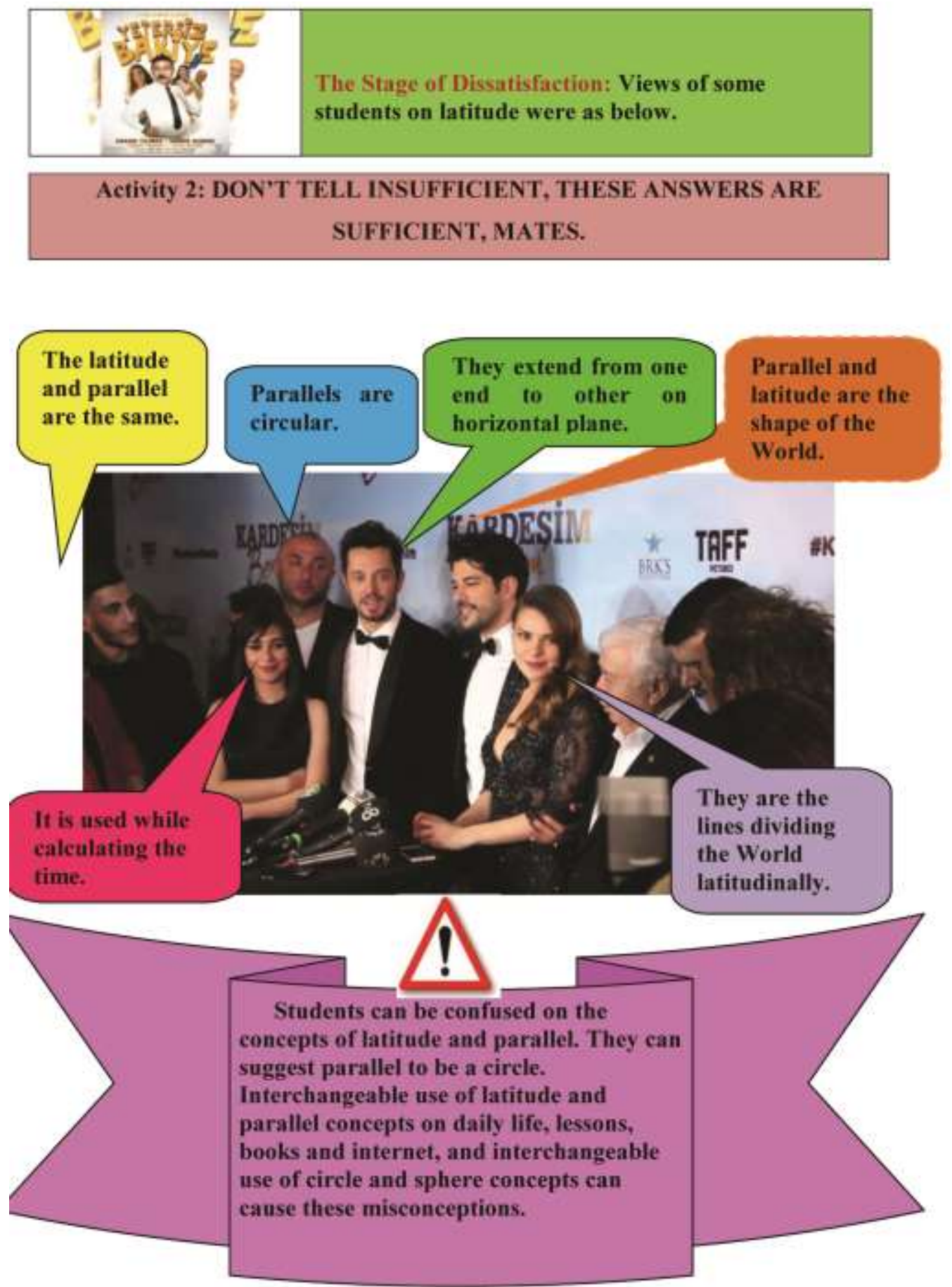


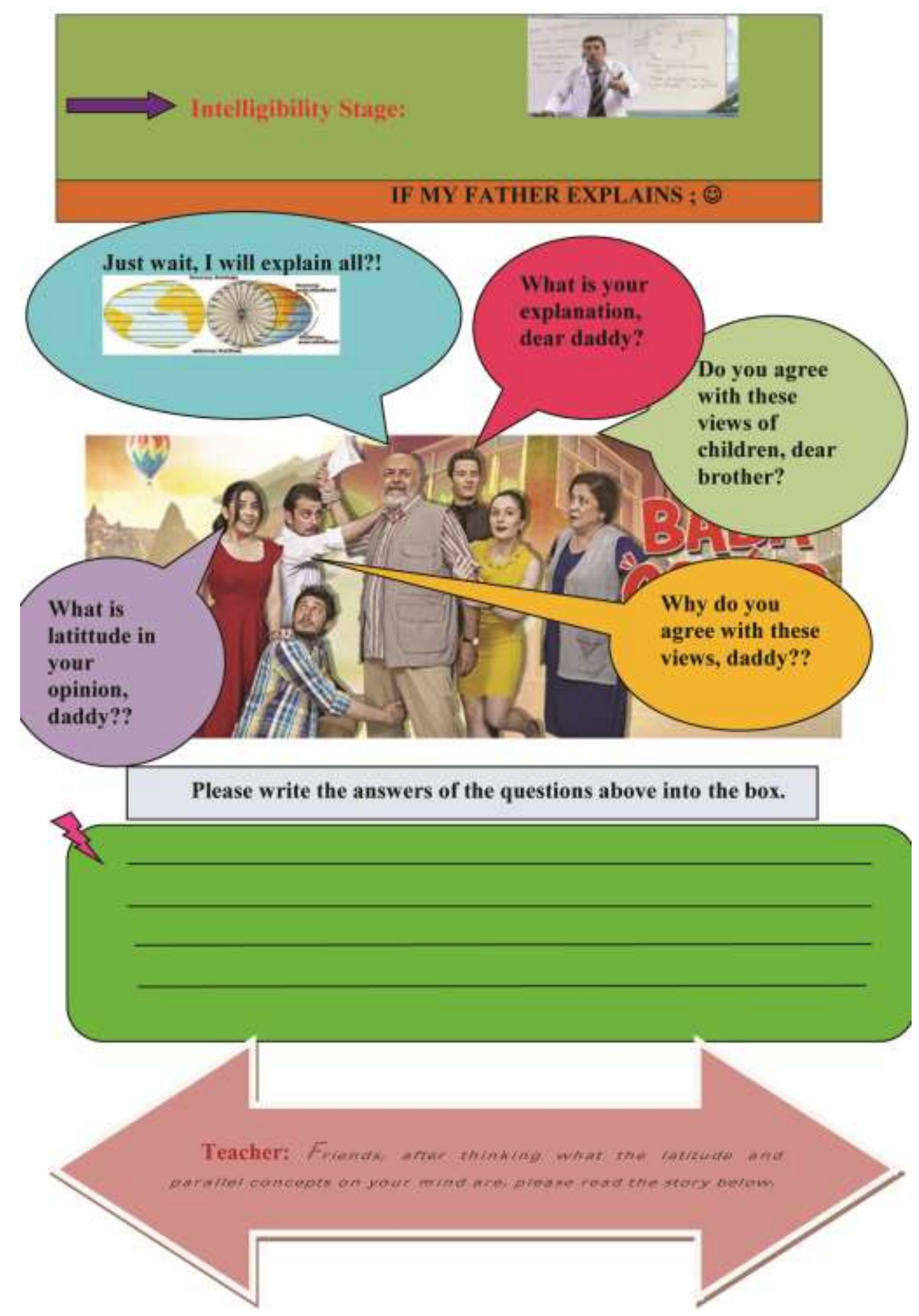



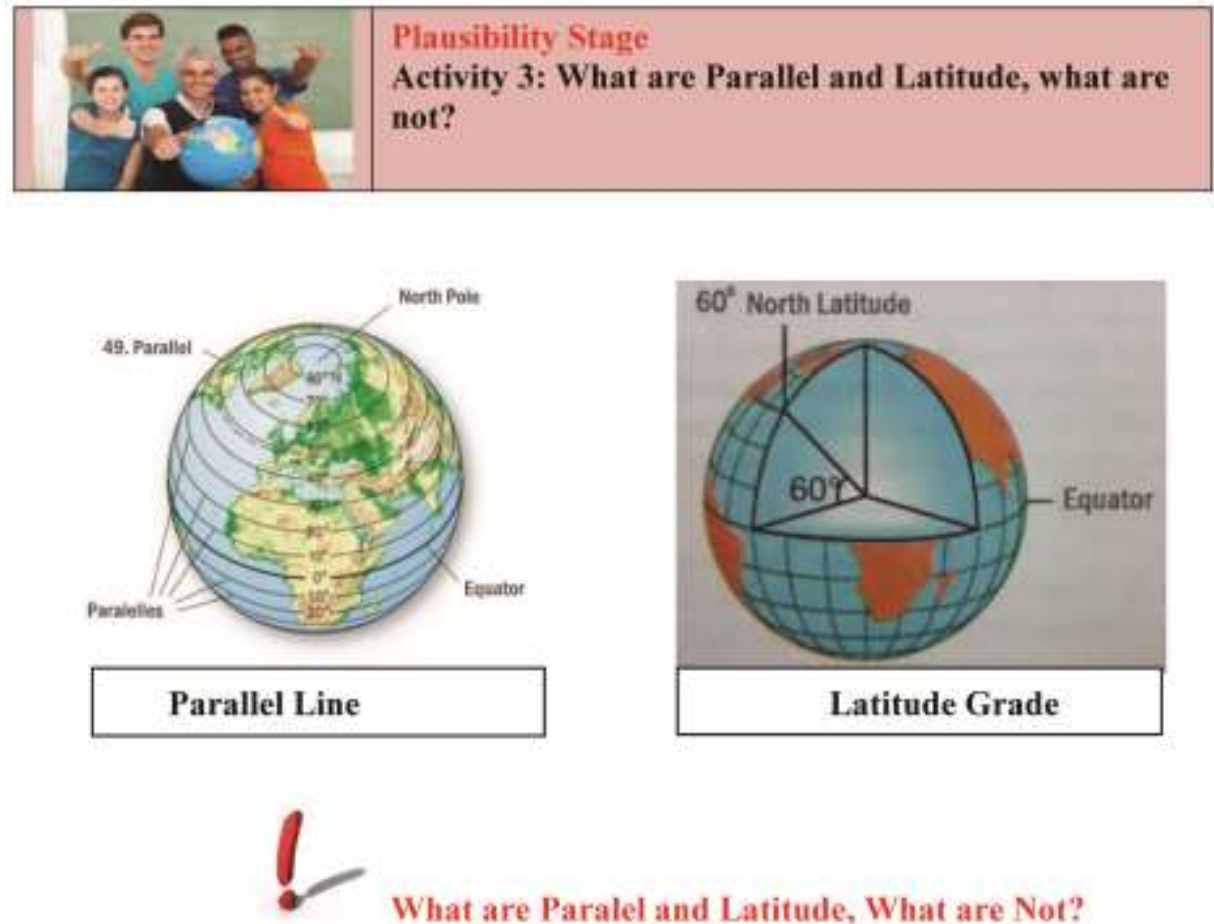

\section{What are Paralel and Latitude, What are Not?}

\section{(Each Parallel is Latitude; However, Each Latitude is Not a Parallel)}

This winter, Erzurum was the host province for 2017 European Youth Olympics Winter Festival (EYOWF) organization. The Olympics committee tried to choose a guide for carrying the sportsmen from the hotel they stayed in the city center to the sports venue. For this, notices were put up, and it was announced from local radio and television that concerned persons could apply. Teacher Ahmet and Ömer who heard the announcements decided to apply for the job for both a support to their family budget and introducing with people from different countries and different cultures. Teacher Ahmet and Ömer who successfully passed the interview of guidance selection committee started the job at the same day, and made their way to the airport in a cold and snowy day. In the list given by the committee, there were the sportsmen from the Republic of South Africa and Argentine located on the south of our country, on the one hand, and sportsmen from Germany, Portugal, and Canada located on the west of our country, on the other.

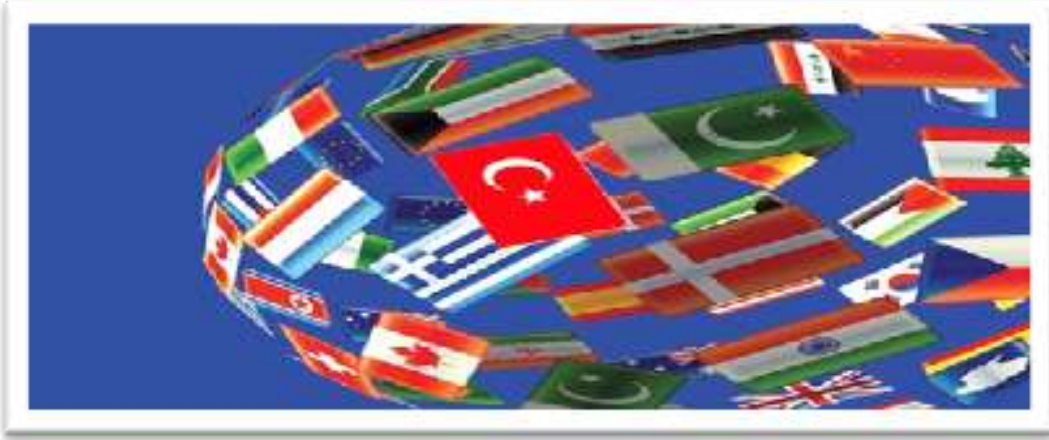

After 45 minutes at the airport, the first groups started to appear on departure gate. These sportsmen were the ones coming from the Republic of South Africa and Argentine. Teacher Ahmet who saw the sportsmen first started to grumble as:

-What is that? They come to our country wearing t-shirts. They are out of their mind, they will get frozen. Haven't they checked the weather condition? Teacher Ömer who smiled what he heard from teacher Ahmet told that:

-This is latitude effect. Because solar rays strike the ground more directly to the countries of these sportsmen, their country is warmer than Turkey. Teacher Ahmet told in a self-confident way that: 
-All right, I remembered, now. We learned it in Geography lesson. There are parallel circles including 90 on the north and 90 on the south in the world that are assumed to divide the World. By the effect of these parallels, the countries on the north of our country are colder, and the countries on the south are warmer, right? Teacher Ömer told in a half smile that:

-Partly. Teacher Ahmet said that:

-How partly? Teacher Ömer replied that:

-The ones you told are not the effect of parallels, these are the effect of latitude; furthermore, THE PARALLELS ARE NOT SPHERES, BUT THEY ARE CIRCLES. Teacher Ahmet told that:

-Namely, they are the same. Teacher Ömer explained that:

-In fact, parallels and latitude are frequently used instead of each other; however, they are not the same. Moreover, sphere occurs through the uniting of circle and inner side of circle together. Inside of a sphere is full. For example, coin, crown cork, etc. The parallels do not cover an area. The parallels are the cluster of dots assumed to appear through joining the dots that are at an equal distance to Equator; namely these are CIRCLES. For example; ring, bagel, etc. Moreover, the parallels are the circles that are assumed to pass through the World with ONE EACH DEGREE INTERVAL. As you told before, they are totally 180 including 90 on the north and 90 on the south. This information is accurate. Also, the interval between each parallel is $111 \mathrm{~km}$. For that reason, they just serve to calculate the distance between the countries. On the other hand, latitudes are the eternal parallels that are possible to be drawn as degree $\left({ }^{0}\right)$, minute ('), and second ("). Namely, as you see, EAC PARALLEL IS A LATITUDE; HOWEVER; EACH LATITUDE IS NOT A PARALLEL.
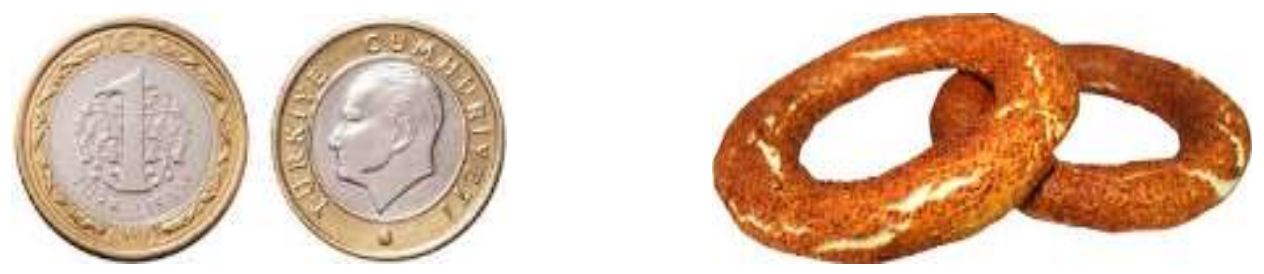

After this explanation, Teacher Ahmet told ashamedly and acridly that:

-You are right. What you explained is right. We have used latitude and parallel as if they are the same for years. I now fully understand that they are not the same, he told. Teacher Ömer who noticed the meaningless look of the sportsmen told that:

-Teacher, they are looking for us, you put up the placard on your hand, and I will call them out, so that they'll notice us. After Teacher Ahmet and Ömer embarked the sportsmen on the bus, they took the road to the hotel. After a nearly 20-minute journey, the bus arrived to the hotel. The hotel staff met the sportsmen with their smiling face at the gate. After Teacher Ahmet and Ömer helped the sportsmen check in the hotel, they said goodbye agreeing on meeting the other sportsmen at 10.00 on the following morning. 

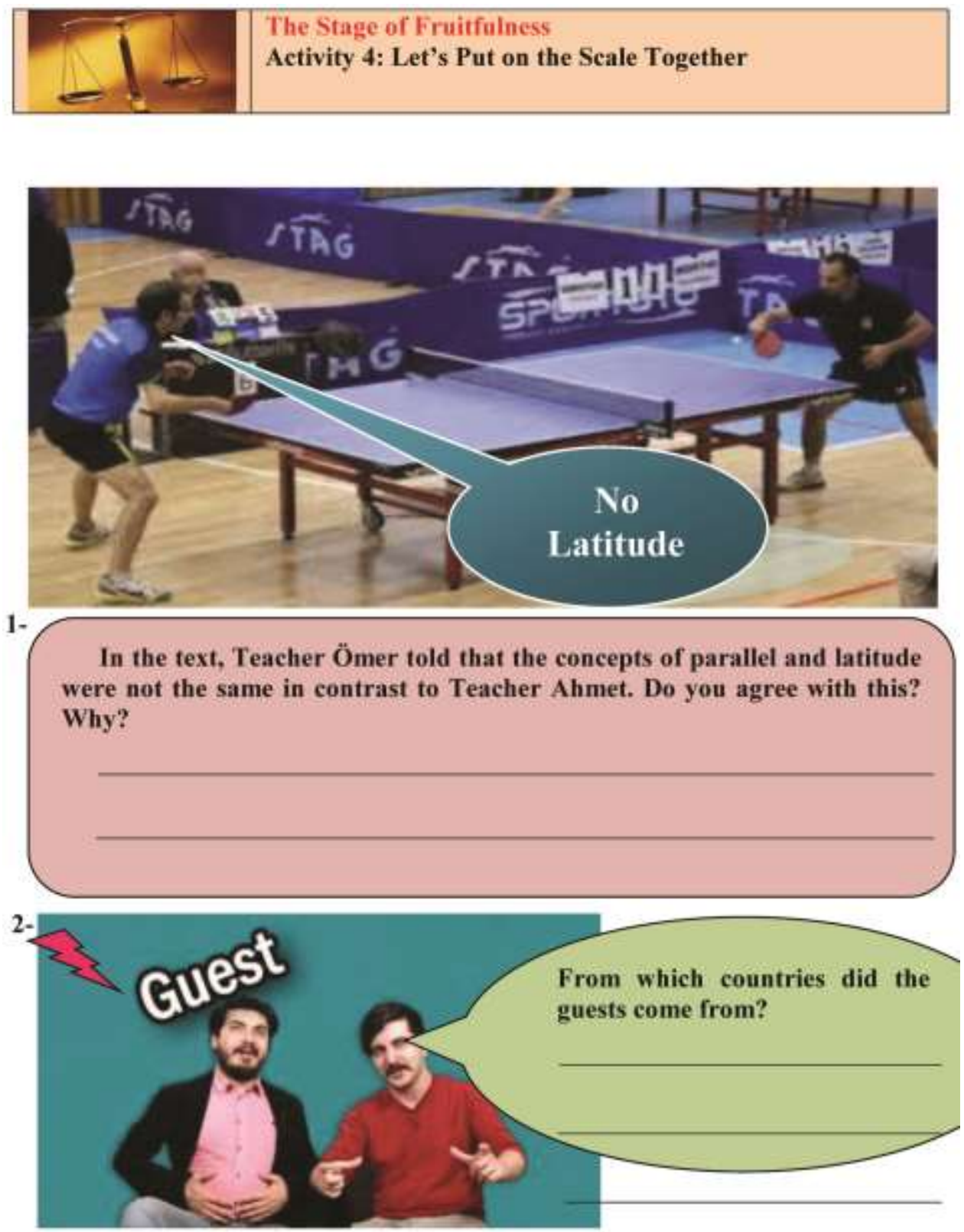
3 -
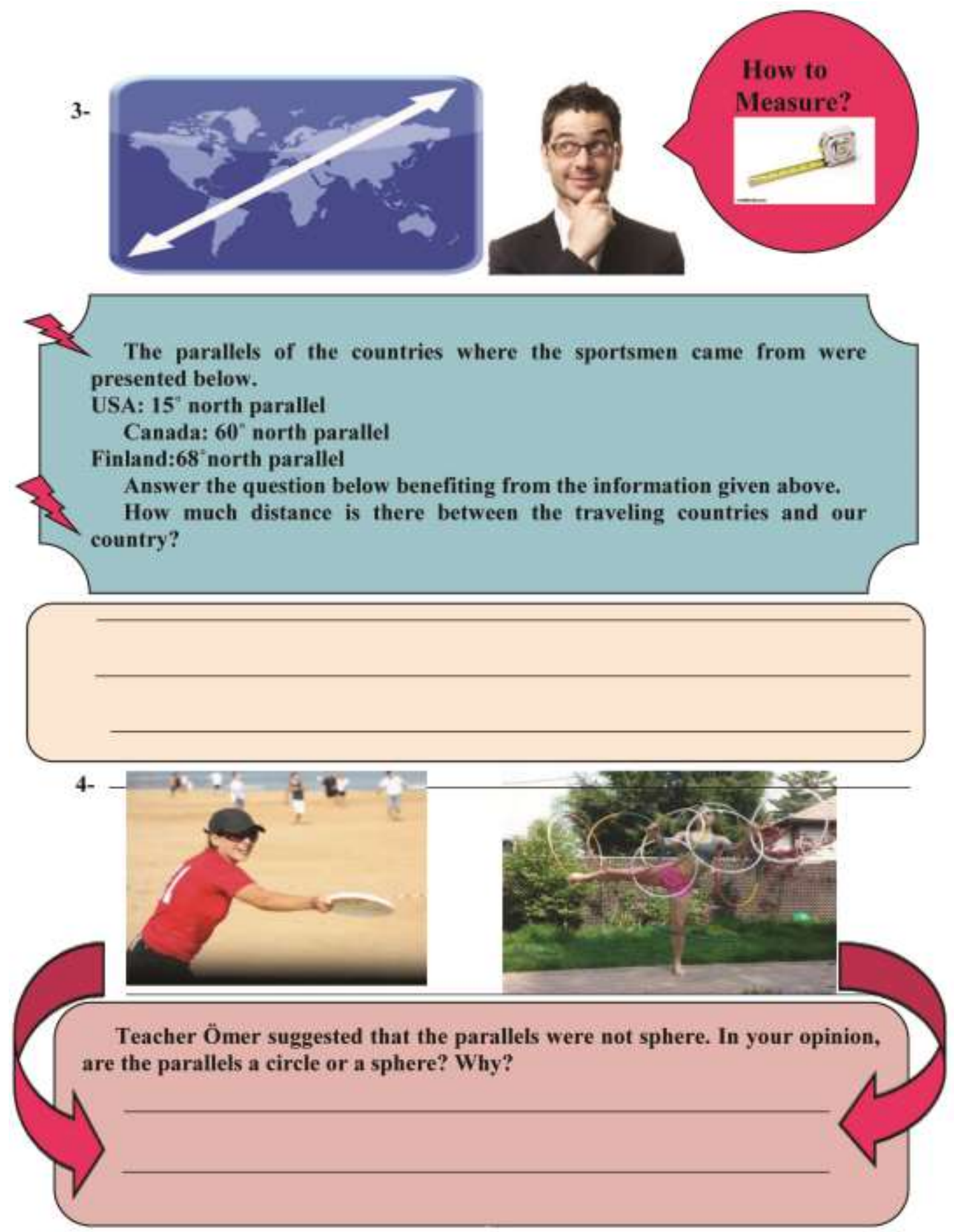